\title{
Ocular abnormalities in the amniogenic band syndrome
}

\author{
LAURENCE S. BRAUDE, ${ }^{1}$ MARILYN MILLER, ${ }^{2}$ AND JIM CUTTONE ${ }^{1}$ \\ From the ${ }^{1}$ Department of Ophthalmology, University of Illinois Hospital Eye and Ear Infirmary, and the \\ ${ }^{2}$ University of Illinois Center for Craniofacial Anomalies, Chicago, USA
}

SUMMARY Craniofacial and limb abnormalities are characteristic of amniogenic band syndrome. We present the ocular findings of a patient with this syndrome and compare these abnormalities with those in 20 previously reported cases.

\begin{abstract}
Amniogenic band syndrome (ring constriction or Streeter dyspasia ${ }^{1}$ is characterised by constriction bands that result in amputations or syndactyly of digits, in the constriction of limbs, or in the amputation of the distal portion of the limbs. ${ }^{23}$ Torpin has explained the bizarre facial clefts at nonappositional sites to be caused by the fetus swallowing one or more of the free-floating strands that result from amniotic rupture. ${ }^{45}$ The tension of these strands intraorally and extraorally produce secondary tears and deformations. Microscopic and macroscopic examination of the bands observed at the sites of constriction has confirmed their amniotic origin. Transitional oligohydramnios after amniotic rupture has been blamed for the club foot deformation commonly associated with these malformations. It is conceivable that the effects of amniogenic bands may be superimposed on an earlier teratogenic lesion, producing a malformation by a different mechanism. The case report described here qualifies as such an example.
\end{abstract}

\section{Case report}

A black female infant has been followed up at the University of Illinois Center for Craniofacial Anomalies and Eye and Ear Infirmary. She is the third child of unrelated parents. Two male siblings had died (1 at 6 weeks from 'crib death' and 1 at 19 months after an accident). There was no family history of congenital defects. The pregnancy had been complicated by urinary infections during the first 2 trimesters. These infections had been treated with ampicillin for 10 to 14 days each. There was no

Correspondence to Dr Laurence S. Braude, University of Illinois Hospital Eye and Ear Infirmary, 1855 West Taylor Street, Chicago, IL 60612, USA. maternal history of trauma, drug ingestion, kernicterus, abortions, or stillbirths.

The patient was a full-term product (birth weight, $3304 \mathrm{~g}$ ) of a vaginal delivery. Her head was normocephalic. A bilateral cleft lip and palate and complete cleft of the secondary palate were noted (Fig. 1). This defect of nose, lip, and palate followed conventional embryonic appositional lines, showed no atypical morphology suggestive of secondary tearing, and was typical of similar defects not associated with amniogenic bands. She also displayed a number of reduction defects and constriction bands of the fingers (Fig. 2). Most of the right foot was absent, and several bands were present in the right lower leg (Fig. 3). She had full range of movement of the extremities and no club foot. Except for the expected reduction of gross motor skills consistent with the limb deformities she has shown normal growth and development.

The ophthalmological examination disclosed a marked upward (mongoloid) slant to the eyes and colobomas in the medial and central thirds of the upper and lower lids (Fig. 4). The punctae were patent on both sides. At 1 year of age the right eye had unsteady fixation, the left eye central steady fixation. Cycloplegic retinoscopy with $0.5 \%$ tropicamide and $0.5 \%$ cyclopentolate hydrochloride (with the patient under nitrous oxide anaesthesia) was $+0.50 /+1.50 \times 180^{\circ}$ in the right eye and $+2.00 /+2.00 \times 180^{\circ}$ in the left. Interpupillary distance was $5.3 \mathrm{~cm}$ (normal range at 1 year, $4.0-5.5 \mathrm{~cm}$ ); inter inner canthal distance was $3.5 \mathrm{~cm}$ (normal range at 1 year, $1.9-2.9 \mathrm{~cm}$ ); inter outer canthal distance was $8.0 \mathrm{~cm}$ (normal range at 1 year, $5 \cdot 6-7 \cdot 2 \mathrm{~cm}){ }^{6}$ She had $16^{\circ}$ of right exotropia and no limitation of the ocular muscles. The conjunctivae appeared normal. Corneal diameters were 11 by $10.5 \mathrm{~mm}$ in the right eye and 11.5 by 11.5 in the left. 
Fig. 1 Infant with amniogenic band syndrome showing upward slant of palpebral fissures, cleft lip and palate, and normal shaped skull.

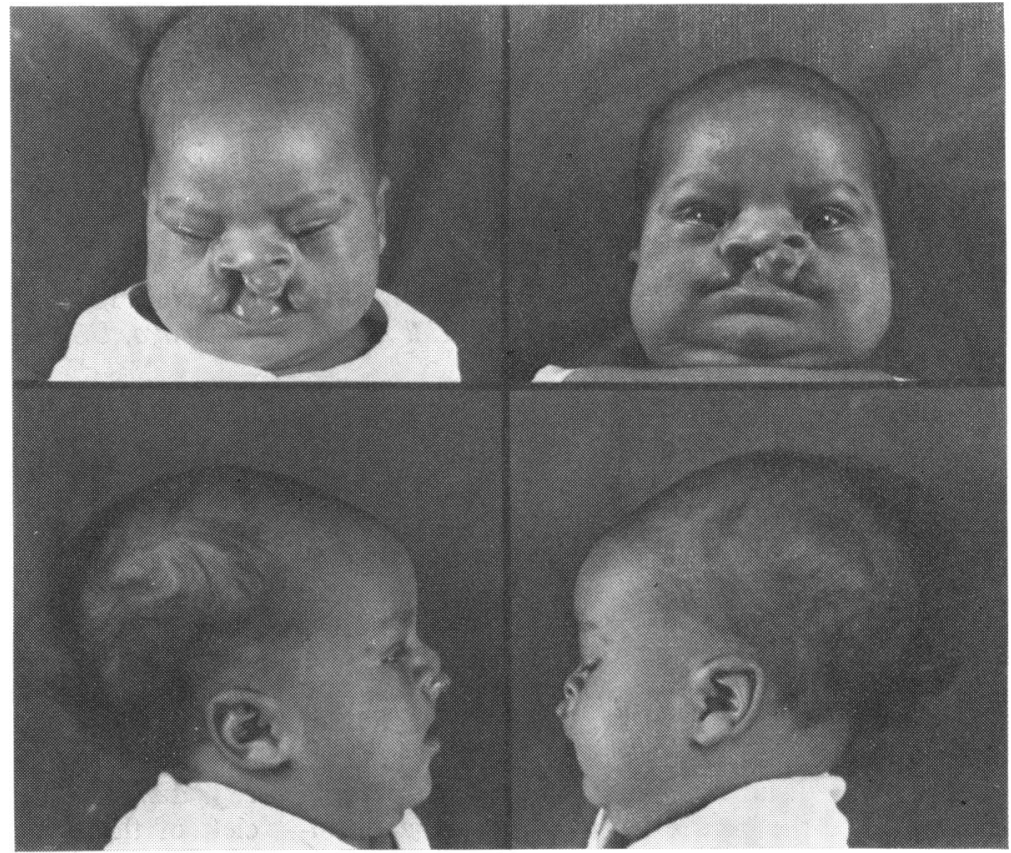

the right but was brisk on the left. The lenses were clear, and discs and maculae appeared normal.

Schiøtz tonometry of the right eye was $24 \mathrm{mmHg}$ with a $5.5 \mathrm{~g}$ weight and $19 \mathrm{mmHg}$ with a $7.5 \mathrm{~g}$ weight. The left eye showed $16 \mathrm{mmHg}$ with the $5.5 \mathrm{~g}$ weight and $12 \mathrm{mmHg}$ with the $7.5 \mathrm{~g}$ weight. Perkins tonometry showed tensions of $13 \mathrm{mmHg}$ on the right and $9 \mathrm{mmHg}$ on the left. The remainder of the physical examination and laboratory test results were unremarkable.

The patient underwent surgery for the repair of

Fig. 2 Patient with anmiogenic band syndrome has ring constrictions and self-amputated stumps on the right hand (left) and normal left hand (right).

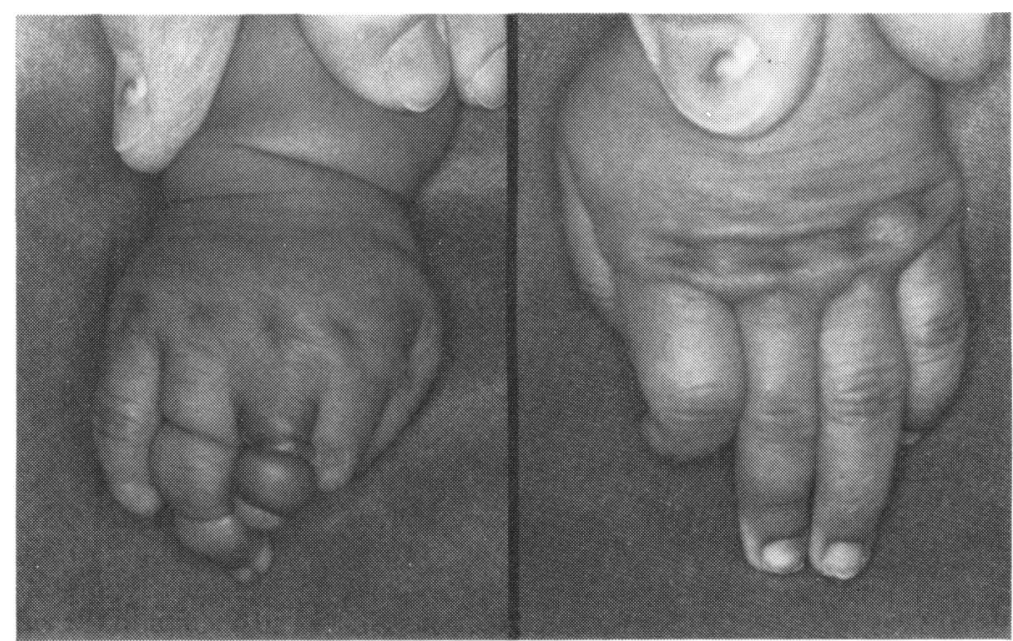




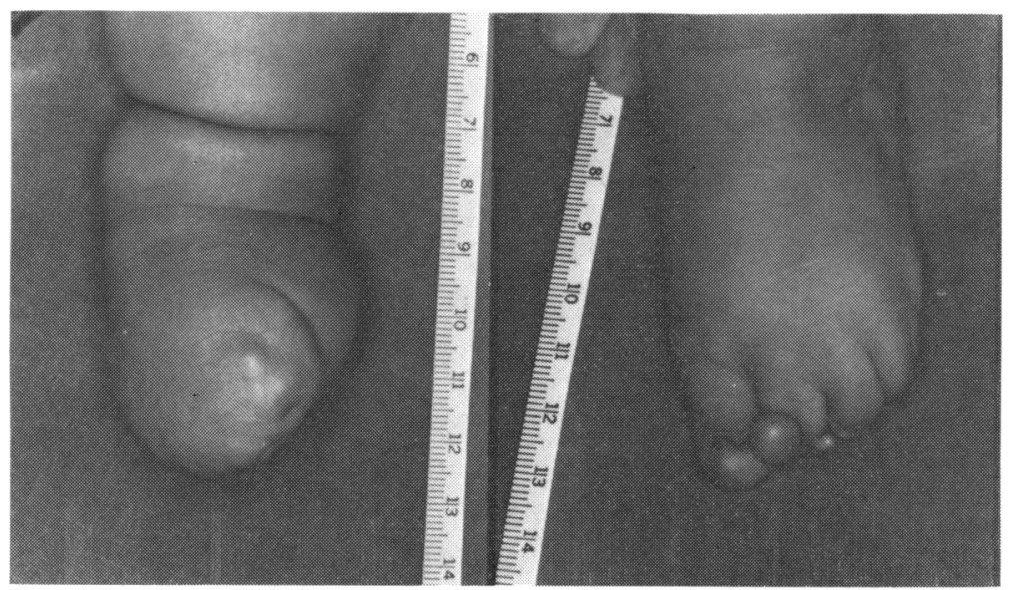

Fig. 3 Patient with amniogenic band syndrome showing absent right foot and ring constriction of lower leg (left) and ring constriction of left second toe (right).

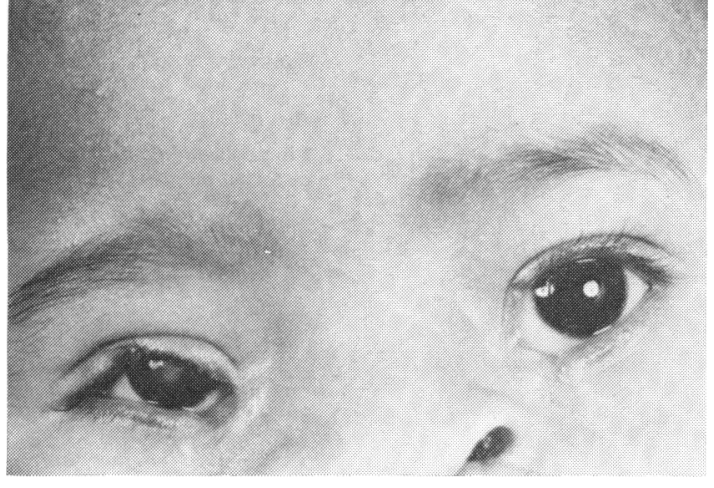

Fig. 4 Amniogenic band syndrome infant has upward slant of both palpebral fissures and bilateral colobomas of upper and lower lids. Small grooves that extend inferonasally from both lower lid colobomas probably represent sites of amniotic band attachment. Corneal leucoma is present in right eye; leucoma of left eye not seen under upper lid.

the colobomas. Procedures were also performed to release the bands of the right and left lower limbs and digits and to repair the cleft lip and palate.

Keratoplasty was not performed to correct the right corneal opacity, as subsequent amblyopia may defeat the most successful result. ${ }^{78}$

\section{Discussion}

The incidence of amniotic bands is 1 in 5000 to 15000 live births..$^{5}$ They are not necessarily more common in low socioeconomic groups. No hereditary factor is known, and the risk of recurrence is not increased for the patient's siblings or offspring. Some authors have postulated that trauma to the uterus during pregnancy causes amniotic rupture. ${ }^{5}$
Proof of amniotic rupture without damage to the chorionic sac is no longer in question. ${ }^{5}$ The strands of amnion may attach to the growing fetus and produce malformations as early as the first trimester. One-third of 327 fetuses in Torpin's series had attachments of the head and mouth at almost all stages of gestation.

We found 19 reported cases of amniogenic band syndrome with eye findings and have summarised these cases in Table 1. Findings in our patient that were similar to those previously reported included upward slant of the palpebral fissures, bilateral upper and lower lid colobomas, telecanthus, and bilateral corneal opacities. The lid colobomas may have been the result of traction on the lids by the amniotic bands, though no such band was seen at birth in our patient. The corneal opacities may have been caused by amniotic band adhering to the cornea with possible perforation. Before the ocular findings

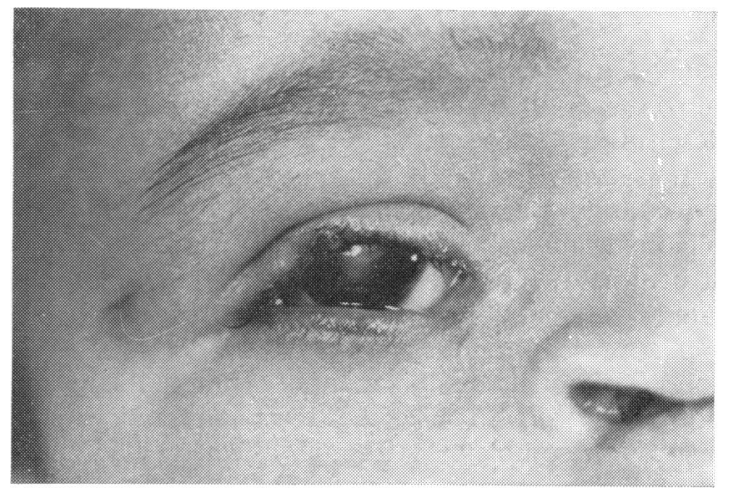

Fig. 5 Right eye of patient with amniogenic band syndrome showing upper and lower lid colobomas and corneal leucoma. Note traction groove from lower coloboma. 
Table 1 Summary of eye findings in 21 cases of amniogenic band syndrome

\begin{tabular}{|c|c|c|c|c|c|c|c|}
\hline $\begin{array}{l}\text { Case } \\
\text { no. }\end{array}$ & Anophthalmos & Microphthalmos & $\begin{array}{l}\text { Facial band } \\
\text { involving eye }\end{array}$ & Hypertelorism & $\begin{array}{l}\text { Corneal } \\
\text { opacity }\end{array}$ & $\begin{array}{l}\text { Lid coloboma } \\
\text { or cleft }\end{array}$ & Other \\
\hline \multicolumn{8}{|c|}{ Broome et al..$^{10}$ ( 8 cases) } \\
\hline 1 & os & & + & & & & \\
\hline 2 & & & + & & & & \\
\hline 3 & OU & - & + & + & & Median lid OS & \\
\hline 4 & os & & + & & + & $\begin{array}{l}\text { 'Scalloped' } \\
\text { eyelid OD }\end{array}$ & $\begin{array}{l}\text { Corneal opacity OD and } \\
\text { misshapen iris OD }\end{array}$ \\
\hline 5 & & & + & + & & & $\begin{array}{l}\text { Cloudy cornea OS and iris } \\
\text { coloboma OS }\end{array}$ \\
\hline 6 & OD & os & + & & & & \\
\hline 7 & - & - & - & - & - & - & $\begin{array}{l}\text { Slight upward slant of } \\
\text { palpebral fissures }\end{array}$ \\
\hline 8 & & & + & & & os & \\
\hline \multicolumn{8}{|c|}{ Higginbottom et al..$^{12}$ (4 cases described in detail in series of 79) } \\
\hline 1 & & & & & & OU & Position of OD distorted \\
\hline 2 & & & & + & & & \\
\hline 3 & & OD & & & os & os & \\
\hline 4 & & & & & & & No ocular abnormalities \\
\hline \multicolumn{8}{|c|}{ Jones et al..$^{11}$ (7 cases) } \\
\hline 1 & - & OU & & & & & First 6 cases had short, \\
\hline 2 & - & OU & & & & & \\
\hline 3 & & Unilateral & & & & & \\
\hline 4 & & Unilateral & & & & & \\
\hline 5 & & Unilateral & & & & & \\
\hline 6 & & Unilateral & & & & & \\
\hline 7 & & & & & & & $\begin{array}{l}\text { No ocular abnormalities } \\
\text { mentioned }\end{array}$ \\
\hline \multicolumn{8}{|c|}{ Beyth et al..$^{2}(1$ case) } \\
\hline 1 & & & & & & & $\begin{array}{l}\text { 'Compressed' supraorbital } \\
\text { ridges and nose; right facial } \\
\text { paresis }\end{array}$ \\
\hline \multicolumn{8}{|c|}{ Braude et al. (1 case) } \\
\hline 1 & - & - & - & + & OU & $\begin{array}{l}\text { Upper and lower } \\
\text { lid colobomas } \\
\text { OU }\end{array}$ & $\begin{array}{l}\text { Upward slant of palpebral } \\
\text { fissures }\end{array}$ \\
\hline
\end{tabular}

Symbols: +, present; -, absent; blank, not mentioned.

can be attributed to amniotic bands, oligohydramnios, or spontaneous malformations, more detailed descriptions are needed.

It is possible that both compressed supraorbital ridges and facial nerve paresis are related to transient oligohydramnios and mechanical pressure on orbital structures in much the same way as Torpin postulated for the aetiology of clubfoot in his series. ${ }^{25}$

The protean manifestations of this disorder are a source of much confusion and prompted Higgenbottom $e t$ al. to use the term amnionic band disruption complex. ${ }^{12}$ Although affected individuals may share a common pathogenic mechanism, no 2 patients have identical clinical patterns.

This study was supported in part by core grant IP30EY01792 and training grant EY703802 from the National Eye Institute; grant DE-02872 from the National Institutes of Health; and a grant from the Maternal and Child Health Sciences.

The authors thank Samuel Pruzansky, DDS, for his helpful comments in reviewing the paper and John Paton, $M D$, for referring this patient.

\section{References}

1 Streeter GL. Focal deficiences in fetal tissues and their relation to intrauterine amputation. Contrib Embryol Carney Inst 1930; 22 : 1-44.

2 Beyth Y, Perlman M, Ornoy A. Amniogenic bands associated with facial dysplasia and paresis $J$ Reprod Med 1977; 18: 83-6.

3 Diamond LS. Ring constrictions: In Bergsma D, ed. Birth Defects Compendium. New York: Liss, 1979: 943-4.

4 Torpin R. Amniochorionic mesoblastic fibrous strings and amnion bands: associated constricting fetal malformation or fetal death. Am J Obstet Gynecol 1965; 91 : 65-75.

5 Torpin R. Fetal Malformations Caused by Amnion 
Rupture During Gestation. Springfield: Thomas, 1968.

6 Pryor H. Objective measurements of interpupillary distance. Pediatrics 1969; 44: 973-7.

7 Waring GO. Congenital central corneal opacity: diagnosis and management. Trans Pac Coast Otoophthalmol Soc 1976; 56: 361-89.

8 Frey T, Friendly D, Wyatt D. Re-evaluation of monocular cataracts in children. Am J Ophthalmol 1973; 76: 381-8.

9 Baker CJ, Rudolph AJ. Congenital ring constrictions and intrauterine amputations. Am J Dis Child 1971; 121: 393-400.
10 Broome DL, Ebbin AJ, Jung AL, Feinauer LR, Madsen $M$. Aberrant tissue bands and craniofacial defects. Birth Defects 1976; 12: 65-79.

11 Jones KL, Smith DW, Hall JD, Ebbin AJ, Massond H, Bolbers MS. A pattern of craniofacial and limb defects secondary to aberrant tissue bands. J Pediatr 1974; 84: $90-5$.

12 Higgenbottom MD, Jones KL, Hall BD, Smith D. The amnion band disruption complex: timing of amnion ruptive and variable spectra of consequent defects. $J$ Pediatr 1979: 95: 544-9. 